\title{
Household rainwater tanks: mediating changing relations with water?
}

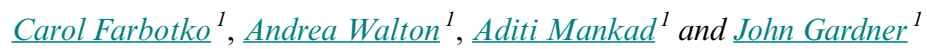

\begin{abstract}
Domestic rainwater tanks have become commonplace in Australia's urban landscape, and have become the physical embodiment of the changing relations between householders, water, and water authorities. The aim of our research was to understand these changing relations by examining how domestic rainwater tanks are inscribed with meanings and assumptions and thus mediate a relationship between households and government. In particular, we considered how domestic rainwater tanks are implicated in various understandings of entitlements to water collected or used in private domains. We examined how tanks can render visible the contestation over rights and obligations of state and citizen as to what is considered private and public water collection, management, and use at the scale of the household. Our exploration of these issues was conducted through a case study of changing water relations in South East Queensland, Australia, where there has been recent widespread installation of domestic rainwater tanks.
\end{abstract}

Key Words: Australia; decentralized water collection; domestic rainwater tanks; household water; private water use; rainwater privatization; rainwater tanks; urban rainwater collection; urban rainwater storage; water rights

\section{INTRODUCTION}

An assurance that water will be channeled to households and managed centrally by government is built into the systems of dams, reservoirs, pipes, and taps that dominate urban water supply in high-consumption societies (Sofoulis 2005). In Australia, this assurance was challenged during the Millennium Drought (1997 to 2009), when reservoirs fell to low levels, and water authorities were confronted with the possibility of being unable to fulfil their taken-for-granted role of supplying ondemand potable water to households (Mankad et al. 2012). Concerns about the political fallout and logistical difficulty associated with taps running dry in Australian cities saw decentralized urban water systems being envisioned as important mechanisms for cost-effective diversification of water supply, particularly for an increasing population in a changing climate (Gardner and Vieritz 2010). Decentralized water technologies at the household scale, such as urban rainwater tanks and gray-water systems, became a focus of policy attention during the drought; a way of achieving catchup to a historical lack of investment in expanding the centralized water infrastructure. Such technologies were viewed as a means of tackling a perceived water-scarcity crisis by providing alternative, lower-than-mains-quality water supplies for nonpotable uses such as watering gardens and flushing toilets (Mankad et al. 2012). Simultaneously, urban householders were cast as having to bear significant responsibility for conservation of public water supplies, which was operationalized in a range of policies including water conservation education campaigns, mandatory water restrictions, user-pay approaches to water pricing, and domestic rainwater tank subsidies (Sofoulis 2005, Bell 2009).

In this context, rainwater falling on the Australian urban landscape became perceived as a wasted public resource. Serendipitous watering of parks and backyard gardens aside, large volumes of urban rainwater were viewed as nonproductive, by falling on concrete and flowing directly down drains, thus escaping catchment by dams (Queensland Water Commission 2010). Attempts to harvest rainwater in the urban environment, no matter how small, were therefore generally regarded as politically acceptable and in the public interest (Brown et al. 2009, Brown 2005). Residential premises - once conceived simply as end-of-pipe destinations for centralized water infrastructurewere re-imagined as appropriate sites for water collection and storage through the use of domestic rainwater tank technology (Gardiner 2009, Gardiner 2010, Moy 2012). Private dwellings with recently installed domestic rainwater tanks thus became useful sites for studying the intertwined forces of changing water supply infrastructure on one hand, and changing practices of domestic water use on the other (Shove 2003): by the time the Millennium Drought ended in 2010, domestic rainwater tanks had become commonplace in the Australian urban landscape, a physical embodiment of changing relations between householders, water and water authorities (Chappells and Shove 1999, van Vliet et al. 2005). The aim of our research is to understand these changing relations, by examining how rainwater tanks are inscribed with meanings and assumptions, and thus mediate a relationship between households and government (van Vliet et al. 2005). In particular, we consider how domestic rainwater tanks are implicated in various understandings of entitlements to water collected or used in private domains (Ahlers and Zwarteveen 2009, Swyngedouw 2009). We examine how tanks can render visible the contestation over rights and obligations of state and citizen to what is considered private and public water collection, management, and use at the scale of the household. Our exploration of these issues was conducted through a case study of changing water relations in South East Queensland (SEQ), Australia, where there has been recent widespread installation of domestic rainwater tanks.

The paper proceeds as follows. First we explain our methods. Then we consider three potentially conflicting roles for domestic rainwater tank users in the South East Queensland water discourse: as suppliers and consumers of privatized rainwater, as possessing a moral obligation to conserve water for the public good, and as bearers of consumers' rights to guaranteed water provided by the state. Next, regarding issues of tank maintenance, we present data obtained from focus groups conducted with domestic rainwater tank users in South East Queensland. Finally, 
we consider the maintenance of domestic rainwater tanks as rendering visible the changing relationships between householders, water, and water-planning authorities that may have important implications for water policy. We argue that if householders are chiefly concerned with tanks as a means of obtaining an independent and free-of-charge water supply, tensions between the privatization of rainwater, conservation of public water supplies, and commoditization of mains water may not be easily resolved.

\section{METHODS}

We used an interpretive and constructivist approach to understanding changing relations between water-planning authorities and householders, as mediated by rainwater tanks. In such an approach, qualitative data are collected for the purposes of interpretation, and analysis is conducted using constructed categories. Interpretive and constructivist research does not set out to reveal the truth about the world, or to uncover causes of particular actions, such as the installation and maintenance of rainwater tanks. Rather, conclusions are drawn as a way to understand interrelations between multiple discourses; in this case, those found in water-planning strategies and in the perceptions of householders. Because interpretive approaches see research as producing situated, partial knowledge, we do not countenance a definitive account of newly installed domestic rainwater tanks, but seek to establish a plausible and credible one (Haraway 1991, Crang and Cook 1995). Interpretive and constructivist research differs epistemologically to positivism, which is broadly concerned with accessing factual information that exists in the world and that can be reliably measured, even if such measures are susceptible to error and are influenced by researcher subjectivities. While control and prediction are important in positivist research, they are not central to interpretive and constructivist approaches, which instead prioritize insight and understanding about social life (Saldanha 2011). We seek to understand the particularities of the case, rather than to enable generalizable findings (Lin 1998).

In South East Queensland, domestic rainwater tank practices and meanings are in an early stage of co-evolution, as many tanks are newly installed (van Vliet et al. 2005). Householders and waterplanning authorities in this region are starting to grapple with the potential problems related to domestic rainwater tanks (Walton et al. 2012). Associated issues of rainwater tank repair and maintenance are providing fruitful territory for exploring perceptions of rights and obligations of state and citizen to private and public water collection, ongoing water management, and water use at the scale of the household. Tank maintenance and repair have long been neglected as topics of social research because of their apparent banality, but it is precisely issues of technology breakdown that can reveal "the tensions between usually hidden infrastructures of supply, the cultures of consumption and coping amongst users ... and the complex politics surrounding interruption, regulation, repair and maintenance" (Graham and Thrift 2007).

Our study included a review of literature on the politics of water, from which emerged three ways in which state-citizen water relations embodied in rainwater tanks can be conceptualized: in terms of the privatization of supply and consumption of rainwater, in terms of conservation of water for the public good, and (since mains water is available to most households) in terms of consumers' rights to guaranteed mains water provided by the state. These three categories informed data collection and analysis.

Two qualitative methods of data collection were undertaken in the case study region of South East Queensland. The two datacollection methods were: a desktop study of changing discourses of household water supply, and focus groups with household tank users. The research question for the first stage of data collection asked: What state-citizen relations are suggested in domestic rainwater tank discourses? In this stage, a review of the key waterplanning strategy document, the South East Queensland Water Strategy (Queensland Water Commission 2010), and of associated policies, commentaries, and analyses, was undertaken to ascertain how domestic rainwater tanks were involved in redefining water discourses in South East Queensland during and following the Millennium Drought. ${ }^{[1]}$ The research question for the second stage of data collection asked: What state-citizen relationship is most prominent among domestic rainwater tank users? In this stage, focus groups, conducted with from household tank users in the region, were used to gather detailed, contextual data on how issues of tank maintenance were governed. They generated a diversity of views on government-citizen relations mediated by tanks through a combination of information sharing and spontaneous discussion (Flick 2010). For the focus groups, 26 participants were recruited from the Brisbane region, with an equal mix of retrofitted and mandated tank owners. Four focus group discussions were held, with 6 or 7 participants in each. Participants were offered AUD\$70 for their time and expenses, and provided with an Information Sheet and Consent Form outlining the study, its minimal risk, the voluntary nature of participation, and the need for informed consent. The focus groups were recorded and transcribed.

The policy documents and focus group transcripts were then analyzed in an iterative process informed by the literature review, to identify particular themes in both the specification and practice of state-citizen relations around domestic rainwater tanks. An interpretive account of these state-citizen relations was developed through multiple readings of the key water-planning instruments and focus group transcripts, and by identifying key patterns of meaning among and across these documents. Evidence of official state rhetoric that positions rainwater tanks in terms of the privatization of supply and consumption of rainwater, conservation of water for the public good, and consumers' rights to guaranteed mains water provided by the state was gathered and summarized. Focus group transcripts were coded thematically, with statements detailing state-citizen relations identified using the following themes, which emerged following multiple critical readings of and across each transcript: control over tank water, freedom of tanks from regulation, tanks as private assets, tanks as public assets, rainwater as a common resource, and value of tank water in relation to mains water. The emphasis placed on each theme collectively by all focus group participants was then qualitatively evaluated and ranked as either high, moderate or low. Each theme was then related to one of the three conceptualizations of how state-citizen water relations are embodied, as informed by the literature review, thus enabling us to rank the importance of each for the group of South East Queensland residents involved in the study. To help us draw 
conclusions, the values placed on the three types of state-citizen water relations in government and citizen discourse were juxtaposed. Then we could draw out possible conflicts between policy and practice in a complex system of water supply that involves both private and public infrastructure as well as sometimes conflicting values of conservation of water for the public good, private control of privately collected water, and guaranteed household water supplied by the state.

\section{RESULTS}

\section{Rainwater tanks and changing discourses of state-citizen relations}

The Millennium Drought was noteworthy as a period of rapid change in water management in many regions of Australia (Gardner and Vieritz 2010). In the populous South East region of the state of Queensland during the drought, the Queensland State Government's water management strategies became newly guided by the principle that "water is a scarce resource to be shared across the region" (Queensland Water Commission 2010). New, diversified systems of water supply were introduced. An extensive infrastructure building program resulted in a grid of interconnected dams, a desalination plant, and water recycling systems. Concomitantly, the approach to water management underwent significant reform and changed from a fragmented system among local government authorities to a deregulated system overseen by the state government. This change resulted in a complex structure that integrated both centralized bulk water suppliers and carriers, and local government-owned water retailers and distributors. The cost of new infrastructure and reformed distribution retailer entities was shared among water users, including households. Urban South East Queensland households that once relied almost exclusively on guaranteed potable mains water for all domestic uses with a pricing structure based on water access became consumers of mains water with a pricing structure based on usage. The effect on household finances was quite significant. The total water and sewerage bill for a household using $250 \mathrm{~kL} / \mathrm{yr}$, for example, was estimated to have risen $43 \%$, from AUD $\$ 813.90$ to $\$ 1166.62$, in the three years from 2007 to 2010 , with about one-third of the total water and sewerage bill, or AUD\$380, being a result of the state government's bulk water charges (Hurst and Moore 2010). South East Queensland homes, meanwhile, were newly positioned as sites for diversification of water supply. Uptake of domestic rainwater tanks was promoted through government subsidies in existing homes (e.g., postpurchase rebates ${ }^{[2]}$ ) and mandated in new homes. What types of state-citizen relations did these changes suggest? In this section we explore three possibilities.

\section{Rainwater: privatization of supply and consumption}

The Queensland government became the facilitator of a new market in domestic rainwater tanks, positioning these technologies as appropriate for helping to manage water scarcity:

\footnotetext{
A large proportion of development in SEQ is located in coastal areas that receive higher rainfall than existing major dam catchments. Rainwater tanks . . provide a way to capture some of this rainfall. Rainwater tanks are able to collect inflows from light rainfall, whereas dams may require 50 millimetres or more of rainfall in the catchment area before run-off commences.

(Queensland Water Commission 2010:70)
}

The facilitation occurred directly, through information campaigns about domestic rainwater tanks, by providing subsidies to rainwater tank purchasers, and by mandating the installation of tanks in new buildings, i.e., in both individual dwellings and office construction. Specifically, the South East Queensland building code stipulated that for individual dwellings, a minimum 5000-L tank was required, and it was to be connected to at least half of the available roof catchment area or $100 \mathrm{~m}^{2}$ (whichever is lesser) and be connected to specific indoor (e.g., washing machine cold tap, toilet flush) and outdoor (e.g., garden hose) endpoints (Department of Housing and Public Works 2008). The facilitation of a new market in domestic rainwater tanks by government also occurred indirectly. Demand was created, not necessarily intentionally, for new sources of household water when the government introduced stringent household water restrictions during the Millennium Drought. Householders with private property rights and/or spare capital to make an investment in a rainwater tank were able to gain private access to an additional, nonmains and unpriced source of water for discretionary use (e.g., watering gardens or topping up pools during water restrictions), as the Queensland government passed legislation establishing the principle that no levies or charges would be placed on the rainwater collected in tanks by households (Gardiner 2009). Arguably, through these policies the government was interested in making rainwater that falls outside the catchment areas for dams, and within private premises, available for private supply and consumption. Privatization is a process through which activities and resources that had not been formally privately owned, managed, or organized are transferred to a new property configuration that is based on some form of private ownership or control (Swyngedouw 2005). Thus, one way in which tanks embodied a change in relations between state and citizen in Queensland, was through the emerging privatization of supply and consumption of rainwater at the domestic scale.

Conservation of water for the public good

The government expected domestic rainwater tanks in South East Queensland, positioned as part of an agenda during the drought to conserve water as a public good, to function as a mechanism to help reduce household consumption of mains water (Beal et al. 2012):

Water from rainwater tanks . . . reduces demand on
drinking water supplies from the SEQ Water Grid. (Queensland Water Commission 2010:47)

The Queensland Water Commission ran a campaign to raise awareness of rainwater tanks as a component of their draft Water Strategy, sending out direct-mail brochures to 1.1 million households in South East Queensland, advertising in newspapers and other forms of media, and hosting community presentations (Queensland Water Commission 2010). Residents (and industry) in South East Queensland were expected by water authorities to engage in "efficient and responsible water consumption" (Queensland Water Commission 2010), and they faced financial penalty if they used excess water. Tanks embodied a request that householders "take more responsibility for their water supply and to learn to steward their water wisely" (Gardner and Vieritz 2010). Although a properly connected rainwater tank was estimated to reduce household water use by one-third, the extent to which domestic rainwater tanks actually facilitated reduced household water consumption was not clear. Attempts to measure water 
savings often returned lower than expected results (Beal et al. 2012). The degree of interconnectivity between rainwater tanks and other water technologies meant that measurements of any rainwater savings provided by tanks alone were extremely difficult (Mankad et al. 2012). This issue was particularly problematic when rainwater tanks interacted with water-saving technologies such as reduced-flow shower heads. Indeed, as the uptake of water-saving technologies in households increased, the accuracy of measurements of water savings by rainwater tanks decreased. Nevertheless, Queensland water-planning authorities maintained a keen interest in quantifying, at regional and state levels, the volumes of water that domestic rainwater tanks were collectively "saving" and contributing to the state's overall water supplies (Moglia et al. 2012, Umapathi 2012). A second way in which tanks embodied changing relations between state and citizen in Queensland was thus defined by a moral expectation that citizens would use their tanks in such a way that they conserved mains water supplies for the collective good.

\section{Consumers' rights to guaranteed mains water provided by the state}

Urban households in South East Queensland had, for generations, experienced water abundance in their homes as the normal state of affairs. Mains water, supplied by government, has been available to urban South East Queensland households since the 1860s (Tisdell et al. 2002). During the Millennium Drought, a discourse of water scarcity was positioned in counterpoint to this everyday experience of abundance. Dam levels during the Millennium Drought fell to below $20 \%$ of capacity, low enough that water authorities were confronted with the possibility of being unable to fulfil an assumed role of supplying on-demand potable water to households (Mankad et al. 2012). However, the taps in South East Queensland households did not run dry during the Millennium Drought (cf. Kaika 2003); water-planning authorities introduced mandatory household restrictions on mains water, which became increasingly severe from 1997 to 2009. These restrictions were met with high levels of householder compliance, as demonstrated by South East Queensland wateruse patterns (Queensland Water Commission 2010). Such measures represented explicit attempts by government to interrupt expectations of water abundance among householders. However, despite evidence that such restrictions were useful for reducing water demand (Beal et al. 2012), water-planning authorities became reluctant to continue using them in postdrought water-planning strategies. The Queensland Water Commission introduced a permanent water-conservation measure of recommended water use as part of the South East Queensland Water strategy, and set an objective that the population of the region should experience water restrictions, on average, no more than once every 25 years, with public health and safety not compromised, and at least cost to the community (Queensland Water Commission 2010):

Infrastructure will be planned so that the frequency of restrictions will be no more than once every 25 years, on average. These restrictions would be much less severe than those that applied during the recent drought, which prohibited almost all outdoor water use.

(Queensland Water Commission 2010:3)
Underlying this strategy was a perceived need to plan for potential climate change and future population growth. Also, there was feared public backlash over perceived rights to guaranteed household water failing to be met by government. This fear needs to be understood not only with reference to postdrought refilling of dams by heavy rains, but in the context of changes that were made to household water bills at around the same time, i.e., when household water charges were changed from access to usage to cover the costs of the new dam and other infrastructure. Householders felt that they were paying for the new dam through hefty water bills (Hurst and Moore 2010); water restrictions seemed to be no longer publically acceptable once piped household water became a relatively high-priced commodity. Householders had become less willing to relinquish their perceived right to guaranteed water provided by government than they had been at the height of the drought, before the new and expensive water grid came online. A third, albeit less direct, way in which tanks embodied changing relations between state and citizen in South East Queensland was thus through an assurance of essentially unrestricted mains water supplied by government, although only to the extent that the household could afford to pay for it. Mains water was newly positioned as a commodity, organized around the availability of and access to capital, replacing its historical status as a public good organized around citizen rights to water (Bakker 2001, Swyngedouw 2006, Roberts 2008). Significantly, this assurance was made around the same time as tanks were being installed in large numbers by householders in the region. Urban households with newly installed tanks were, for the most part, required to remain connected to the mains water supply for potable purposes, as public health regulations discouraged the use of tanks for drinking, bathing and cooking water.

In sum, three changes in the state-citizen relationship emerged from discourses of domestic rainwater tanks during and following the Millennium Drought: rainwater privatized for household supply and consumption, a moral expectation of households to contribute to ongoing public water supply conservation, and water infrastructure profitability. Almost simultaneously, households with tanks were: granted, through tank policy, usage of discretionary water that was dependent chiefly on rainfall and on access to capital, asked to reduce overall mains water consumption for the public benefit, and required to repay investment in centralized water infrastructure as a consumer of mains water. Domestic rainwater tanks were thus associated with at least three somewhat contradictory new relationships between state and citizen: by the privatization of consumption and supply of water for discretionary use at the domestic scale; by a moral duty of citizens to conserve water for the collective good; and by a consumer, rather than citizen, basis for the guarantee of mains water. It is important to understand householder perceptions of tank usage with reference to these newly envisaged state-citizen relations, which we turn to in the next section.

\section{Rainwater tanks and changes in state-citizen relations}

How were the changes in water discourse as discussed in the previous section, engendered in perceptions of state-citizen relations among South East Queensland households? Tank uptake in the region was vigorous, with an estimated 200,000 rainwater tanks being installed in urban households in South East Queensland between July 2006 and December 2008, and 60,000 
Table 1. State-citizen relations identified in focus group data.

\begin{tabular}{|c|c|c|c|}
\hline $\begin{array}{l}\text { State-citizen } \\
\text { relationship } \\
\end{array}$ & Theme & Significance & Focus group extracts: examples \\
\hline \multirow[t]{3}{*}{$\begin{array}{l}\text { Privatization of supply } \\
\text { and consumption of } \\
\text { rainwater }\end{array}$} & $\begin{array}{l}\text { Water saved for private, } \\
\text { discretionary use }\end{array}$ & High & $\begin{array}{l}\text { I think water tanks are a great way to save using town water; it } \\
\text { allows water to be used FREELY on the garden / car washing, etc. } \\
\text { I like that we can store our own water for our own purposes. } \\
\text { Guilt-free water for pool top-up and car cleaning ... we decide } \\
\text { when and how it is used. }\end{array}$ \\
\hline & $\begin{array}{l}\text { Minimal government } \\
\text { regulation of tanks is } \\
\text { desirable }\end{array}$ & High & $\begin{array}{l}\text { People will be wary about being on a register; talking fees, what is } \\
\text { the hidden agenda? } \\
\text { What's the implication if they inspect it, find something wrong } \\
\text { with my tank and then I decide I don't want to fix it? Well then I'm } \\
\text { penalized or fined. }\end{array}$ \\
\hline & $\begin{array}{l}\text { Tanks are private, not } \\
\text { public, assets }\end{array}$ & Moderate & $\begin{array}{l}\text { My biggest concern is that eventually we will be billed for the water } \\
\text { we get from tanks, that it will become a bill. } \\
\text { And what will a register do, so that they can charge you to have the } \\
\text { tank? }\end{array}$ \\
\hline \multirow[t]{2}{*}{$\begin{array}{l}\text { Conservation of water } \\
\text { for the public good }\end{array}$} & $\begin{array}{l}\text { Tanks are public, not } \\
\text { private, assets }\end{array}$ & Low & $\begin{array}{l}\text { The government has invested a lot of money in water tanks in the } \\
\text { way of rebates. I'd like to think the government undertook some } \\
\text { duty of care to protect that investment. }\end{array}$ \\
\hline & $\begin{array}{l}\text { Rainwater is at least partly } \\
\text { a common resource }\end{array}$ & Low & $\begin{array}{l}\text { Rainwater is a wasted resource if not collected. } \\
\text { Tanks are part of the solution for managing water. }\end{array}$ \\
\hline $\begin{array}{l}\text { Consumers' rights to } \\
\text { guaranteed mains water } \\
\text { provided by the state }\end{array}$ & $\begin{array}{l}\text { Tank water valued in } \\
\text { relation to commoditized } \\
\text { mains water }\end{array}$ & High & $\begin{array}{l}\text { I feel a bit cynical about this if we get so efficient at doing this then } \\
\text { that means we save a lot of water. No one's using enough water so } \\
\text { they increase the rate of water to make up the budget shortfall. } \\
\text { Feel like no matter what you do the water bills are just going to } \\
\text { keep going up. } \\
\text { It comes down to price, because I don't value it really; my water } \\
\text { bill just keeps going up so therefore what's the point of it? } \\
\text { I'm very cynical; they just want to know how much money is } \\
\text { sitting out there in tanks and so that they can bill more. }\end{array}$ \\
\hline
\end{tabular}

of these being installed in new dwellings (Chong et al. 2011, Queensland Water Commission 2010). But what state-citizen relationship, if any, was prominent? We explored these questions in focus groups through issues of tank maintenance. From a householder perspective, mains water systems have typically not involved significant maintenance activities on their part (at least, not past the leaky tap) (Mankad et al. 2012). Questions of tank maintenance were, therefore, useful because they could make visible the changing relations between householders, tanks, tank water, and authorities, but in such a way that they did not normatively pre-position tank users as possessing a moral duty to save water, as suppliers and consumers of privatized water, or as bearers of a right to guaranteed mains water consumption. Rather, by discussing with households government intervention strategies to facilitate the ongoing operation and performance of household rainwater tanks into the future (see Walton et al. 2012), it was possible to examine if, and how, new state-citizen relations were being favored by householders in discussions about their tank practices.

Themes corresponding to each of the three state-citizen relations were identified following multiple critical readings of the focus group transcripts and were cross-checked with key ideas about public and private water identified in the literature review (Table 1). Privatization of supply and consumption of rainwater were mapped to significant participant concerns about control over tank water and freedom of tanks from regulation, and moderate concern about tanks as private assets. Conservation of water for the public good was mapped to low participant concerns about tanks as public assets and rainwater as a common resource. Consumers' rights to guaranteed mains water provided by the state was mapped to high participant concerns about value of tank water in relation to mains water.

Table 1 shows that among focus group participants there was considerable anxiety about government regulation of household tanks on the one hand (including their revenue-raising potential), and strong desires for tank maintenance and use to be matters of individual choice on the other. Householders in the region were largely concerned with domestic rainwater tanks, and the water they collected, as private rather than public resources. In their water-planning strategy, the government had taken rainwater that fell outside the catchment areas for dams and made it available for both private ownership and to contribute towards 
conservation of public water supplies. However, domestic rainwater tanks were embraced by householders largely as a means of privatization of water supply and consumption, which outweighed a sense of moral duty to conserve water supplies for the public good. Furthermore, as the extracts in Table 1 make clear, tank users understood their tanks in the context of significantly higher bills for mains water that they paid following the boom in tank uptake. Indeed, they were concerned that effective use of their tanks for conservation of public supply would result in unwanted tank regulation, higher charges for mains water, and perhaps charges for tank water.

\section{DISCUSSION}

Water discourses in South East Queensland broadly positioned householders as possessing an abstract moral duty to conserve water supplies for the collective good. Various policies attempted to present householders with as much choice and as little regulation as possible in achieving this goal, and addressed householders as consumers of tanks and tank water. The specification of a voluntary target of maximum consumption of $200 \mathrm{~L} /$ person/day, for example, was to be achieved "without significantly changing the lifestyle that South East Queensland residents enjoy" (Queensland Water Commission 2010). Water authorities assumed that financial considerations were likely to motivate householders to install rainwater tanks, and facilitated uptake of rainwater tanks largely through market mechanisms. Most householders could choose whether or not to retrofit their homes with tanks, and they could choose whether or not to take advantage of government subsidies in doing so. It may have been an idealized citizen-consumer that government was hoping to engage through domestic rainwater tanks to achieve both the goal of expanded water supply and the goal of water conservation: one who had access to the capital required to purchase goods in the market that the government deemed useful for social and ecological ends, as well as the desire to engage in conservation of public water resources.

However, householders in the focus groups in this study more closely resembled privatized water suppliers than consumercitizens. For the focus group participants, rainwater tanks were largely perceived as a means of privatizing rainwater, a way of disentangling some household water consumption from regulation, in the context of changing expectations of guaranteed mains water. Tank users valued regulatory autonomy over material autonomy. They valued the freedom of having largely unregulated tank usage and discretionary water not subject to the pricing or restrictions of mains water, over independence from the grid (cf. Gardiner 2010, Gardner and Vieritz 2010). They were expressing a preference to operate their tanks according to central tenets of neoliberalism, namely, that regulation of activities by the state would be minimal, and any water collected in tanks would be available only for private, discretionary use, rather than used chiefly with conservation for the public good in mind (see also Moy 2012). Rainwater collected in tanks in Australia has been found to be "always" more expensive than mains water (Gardner and Vieritz 2010); households were exercising a perceived consumers' right to do as they saw fit with this luxury water. Despite legislation promising that no levies or charges would be placed on the rainwater collected in tanks by households, householders showed considerable skepticism and disapproval of government attempts to exercise any form of control over tanks and tank water. They most particularly resented the idea that government would attempt to use tanks to generate revenue. Rainwater was not seen by households as chiefly a common resource to be shared equitably, but rather as a scarce good over which private rather than social considerations should dominate.

For tank households, the value of tank water was intertwined with the new positioning of mains water as a commodity that the new water bills represented. In this context, households with tanks became more, not less, protective of a perceived right to guaranteed mains water provided by government. However, mains water and tank water were both to be enjoyed as private commodities rather than preserved as a social good. Our findings are supported by a study of motivations for tank installation in South East Queensland in which:

Only five per cent of 200 respondents referred to
community responsibility because of drought and limited
mains water supplies as relevant to their decision to install
a tank. More common motivations were to achieve
independence from water use restrictions, to get the
rebate and to top up the pool... Three quarters strongly
agree with the statement that the water is their own
private resource and that they like the feeling of
independence it gives them. These people would greatly
resent any regulation of their tank water
(Gardiner 2009).

The same study also suggested that a number of tank installers did not apply for government rebates because there was a fear that their tank would be subject to subsequent regulation and that their contact details would facilitate unwanted approaches from authorities (Gardiner 2009).

Given the results of this study, it is not surprising that waterplanning authorities in South East Queensland are encountering tensions between the need to maintain a stake in household rainwater tanks to advance social considerations such as water conservation and public health, and to be seen as nurturing the value householders are finding in privatizing rainwater for discretionary uses (Gardiner 2010, Gardner and Vieritz 2010; see also Barrett and Wallace 2011). To address this tension, waterplanning authorities may need to more fully take into account how householders are positioning the privatization of rainwater in direct relation to the commoditization of mains water. In other words, as long as tank households are connected to mains water, the value placed on rainwater by householders collected in tanks needs to be understood with reference to the way they value the mains water supply. As Gardiner (2010) observes, there is a risk that domestic rainwater tanks will not be used if mains water is freely available, as the value of tank water is in its replacement for water that is not available publicly at any cost. On the other hand, there are important social considerations if mains water is subject to significant price rises. In the South East Queensland context, tank uptake was dependent on the availability of privately owned capital to make a perceived investment in a water tank; rather than, for example, on the basis of a social need. Tanks, therefore, did not improve access to water evenly, to the detriment of those without the financial resources to pay for tanks or to absorb increasing costs of water. 


\section{CONCLUSION}

Scholars of the politics of water frequently argue that, whereas water policy was once characterized by centralized state water systems that prioritized social equity, the priority now is likely to be economic equity, which is based on the principle that users should pay the full cost of what they impose on the system (Bakker 2001). Further, it is widely observed that this shift has resulted in a restructuring of water relations, whereby ideas about the right to water based on social citizenship have given way to a situation where water is organized around the availability of and access to capital (Swyngedouw 2006, Roberts 2008). We have explored how, in instances of water scarcity, it can be useful to characterize changing relations between households, water, and waterplanning authorities as a contestation, not only over economic and social equity but also environmental equity. Our study confirms that, in South East Queensland, supplementing water supply with small-scale, decentralized systems at the household scale may not, through technological change alone, advance environmental objectives such as reducing pressure on common water resources (Shove 2003, Seyfang 2005, Sofoulis 2005, van Vliet et al. 2005, Davison 2011, Moy 2012). Household water technologies such as domestic rainwater tanks can, however, be usefully understood in terms of how they are embedded in changing relations between state and citizen. In South East Queensland, households with tanks were almost simultaneously asked to reduce water consumption for the public good, granted usage of discretionary water that was dependent chiefly on access to capital and rainfall through tank policy, and mandated through mains water-usage bills to repay investment in centralized water infrastructure. Householders expressed little sense of a moral duty to conserve water supplies for the public good, but understood their tanks in terms of significantly higher bills for mains water that they began paying around the same time as the boom in tank uptake. Domestic rainwater tanks were embraced by householders largely as a means of privatization of water supply and consumption, at least in part a response to the commoditization of mains water to which their homes were obliged to remain connected.

A final point to note is that there is a difference between privatization of water by households and privatization of water by corporations, not least because privatization of rainwater is different to its commoditization. For South East Queensland households, tank water was not commoditized. Households did not see their tanks as being financially beneficial; specifically they did not contribute significantly to reduced household water bills, particularly after tank outlay and operating costs of attached electric pumps were taken into account (see also Gardner and Vieritz 2010). Yet households indicated a desire for control over water collected in their tanks. In the absence of substantial regulation of domestic rainwater tanks, water authorities were effectively relinquishing some of the traditional functions of state water supply to households, such as decision-making transparency and operational control. The householders taking up these functions were also citizens, arguably with an entitlement to participation in the management of public water resources. Whether they also had an obligation to practice a moral duty to conserve water supplies for the collective good was, in the eyes of South East Queensland households, not necessarily a given. Tank households were, by insisting on the privatization of supply and consumption of rainwater, exercising their right as citizens to express a preference for a particular model of water management. This model was a neoliberal one, which the water-planning authorities had promoted and accommodated. Only lip service seemed to be paid to the goal of conservation of public water supply, while planning was ultimately concerned with the expansion of supply to meet demand, even under low rainfall conditions. On the other hand, the privatization of rainwater in domestic rainwater tanks by households may also be interpreted as a refusal to accept a perceived contradiction in water-planning (Swyngedouw 2005): attempts by the government to profit from household consumption of mains water at the same time as urging households to reduce their consumption for the public good may not be well-received.

Responses to this article can be read online at: http://www.ecologyandsociety.org/issues/responses. $\mathrm{php} / 6632$

\section{Acknowledgments:}

The research on which this paper is based was funded by the Urban Water Security Research Alliance, Australia.

\section{LITERATURE CITED}

Ahlers, R., and M. Zwarteveen. 2009. The water question in feminism: water control and gender inequities in a neo-liberal era. Gender, Place and Culture: a Journal of Feminist Geography 16:409-426. http://dx.doi.org/10.1080/09663690903003926

Bakker, K. 2001. Paying for water: water pricing and equity in England and Wales. Transactions of the Institute of British Geographers 26:143-164. http://dx.doi.org/10.1111/1475-5661.00012

Barrett, G., and M. Wallace. 2011. An institutional economics perspective: the impact of water provider privatisation on water conservation in England and Australia. Water Resources Management 25:1325-1340. http://dx.doi.org/10.1007/s11269-010-9747-0

Beal, C. D., A. Sharma, T. Gardner, and M. Chong. 2012. A desktop analysis of potable water savings from internally plumbed rainwater tanks in South-East Queensland, Australia. Water Resources Management 26:1577-1590. http://dx.doi. org/10.1007/s11269-011-9973-0

Bell, S. 2009. The driest continent and the greediest water company: newspaper reporting of drought in Sydney and London. International Journal of Environmental Studies 66:581-589. http://dx.doi.org/10.1080/00207230903239220

Brown, R. R. 2005. Impediments to integrated urban stormwater management: the need for institutional reform. Environmental Management 36:455-468. http://dx.doi.org/10.1007/s00267-004-0217-4

Brown, R. R., N. Keath, and T. H. F. Wong. 2009. Urban water management in cities: historical, current and future regimes. Water Science and Technology 59:847-855. http://dx.doi. org/10.2166/wst.2009.029

Chappells, H., and E. Shove. 1999. The dustbin: a study of domestic waste, household practices and utility services. 
International Planning Studies 4:267-280. http://dx.doi. org/10.1080/13563479908721739

Chong, M. N., S. Umapathi, A. Mankad, A. Sharma, and T. A. Gardner. 2011. Benchmark analysis of water savings by mandated rainwater tank users in South East Queensland (Phase 2). Technical Report No. 49. Urban Water Security Research Alliance, City East, Queensland, Australia.

Crang, M., and I. Cook. 1995. Doing ethnographies. Geobooks, Norwich, UK.

Davison, A. 2011. A domestic twist on the eco-efficiency turn: environmentalism, technology, home. In R. Lane and A. GormanMurray, editors. Material Geographies of Household Sustainability. Ashgate, Farnham, surrey, UK.

Department of Housing and Public Works. 2008. Queensland Development Code MP4.2 - Water Savings Targets. Brisbane, Queensland, Australia.

Flick, U. 2010. An introduction to qualitative research. Sage, London, UK.

Gardiner, A. 2009. Domestic rainwater tanks: usage and maintenance patterns in South East Queensland. AWA Water Journal 36:151-156.

Gardiner, A. 2010. Do rainwater tanks herald a cultural change in household water use? Australasian Journal of Environmental Management 17:100.

Gardner, T., and A. Vieritz. 2010. The role of rainwater tanks in Australia in the twenty first century. Architectural Science Review 53:107-125. http://dx.doi.org/10.3763/asre.2009.0074

Graham, S., and N. Thrift. 2007. Out of order: understanding repair and maintenance. Theory, Culture \& Society 24:1-25. http:// dx.doi.org/10.1177/0263276407075954

Haraway, D. J. 1991. Simians, cyborgs, and women: the reinvention of nature. Routledge, New York, New York, USA.

Hurst, D., and Moore, T. 2010 October 27. Water bill plan 'could backfire'. Brisbane Times. [online] URL: http://www. brisbanetimes.com.au/environment/water-issues/water-bill-plancould-backfire-20101026-172cx.html

Kaika, M. 2003. Constructing scarcity and sensationalising water politics: 170 days that shook Athens. Antipode 35:919-954. http:// dx.doi.org/10.1111/j.1467-8330.2003.00365.X

Lin, A.C. 1998. Bridging positivist and interpretivist approaches to qualitative methods. Policy Studies Journal 26:162-180. http:// dx.doi.org/10.1111/j.1541-0072.1998.tb01931.x

Mankad, A., M. N. Chong, T. Gardner, and A. Sharma. 2012. Examining biophysical and socio-demographic factors across mandated tank users in urban Australia: a linking step towards achieving best practices. Water Resources Management 26:1983-1998. http://dx.doi.org/10.1007/s11269-012-0003-7

Moglia, M., A. K. Sharma, G. Tjandraatmadja, A. Walton, and J. Gardner. 2012. Strategies for managing the condition of rainwater tanks in South East Queensland. In proceedings of Urban Water Security Research Alliance (UAWRA) Science Forum and Stakeholder Engagement: Building Linkages,
Collaboration and Science Quality, 19-20 June 2012, Brisbane, Australia.

Moy, C. 2012. Rainwater tank households: water savers or water users? Geographical Research 50:204-216.

Queensland Water Commission. 2010. South East Queensland water strategy. The State of Queensland, Brisbane, Australia.

Roberts, A. 2008. Privatizing social reproduction: the primitive accumulation of water in an era of neoliberalism. Antipode 40:535-560. http://dx.doi.org/10.1111/j.1467-8330.2008.00623.x

Saldaña, J., Leavy, P., and Beretvas, N. 2011. Fundamentals of qualitative research. Understanding Qualitative Research series. Oxford University Press, New York, New York, USA.

Seyfang, G. 2005. Shopping for sustainability: can sustainable consumption promote ecological citizenship? Environmental Politics 14:290-306.

Shove, E. 2003. Comfort, cleanliness and convenience: the social organization of normality. New Technologies/New Cultures Series. Berg, Oxford, UK, and New York, New York, USA.

Sofoulis, Z. 2005. Big water, everyday water: a sociotechnical perspective. Continuum: Journal of Media \& Cultural Studies 19:445-463. http://dx.doi.org/10.1080/10304310500322685

Swyngedouw, E. 2005. Dispossessing H2O: the contested terrain of water privatization. Capitalism Nature Socialism 16:81-98. http://dx.doi.org/10.1080/1045575052000335384

Swyngedouw, E. 2006. Power, water and money: exploring the nexus. Human Development Report Office Occasional Paper, Human Development Report 2006. Human Development Report Office, United Nations Development Programme, and Centre for the Environment, School of Geography, Oxford University, Oxford, UK.

Swyngedouw, E. 2009. The political economy and political ecology of the hydro-social cycle. Journal of Contemporary Water Research \& Education 142:56-60. http://dx.doi.org/10.1111/ j.1936-704X.2009.00054.X

Tisdell, J., J. Ward, and T. Grudzinski. 2002. The development of water reform in Australia. Technical Report 02/05. The Cooperative Research Centre for Catchment Hydrology, Griffith University, Brisbane, Australia.

Umapathi, S. 2012. Monitoring of residential rainwater tanks in South East Queensland to investigate mains water savings and volumetric reliability. In proceedings of Urban Water Security Research Alliance (UAWRA) Science Forum and Stakeholder Engagement: Building Linkages, Collaboration and Science Quality, 19-20 June 2012, Brisbane, Australia.

van Vliet, B., H. Chappells, and E. Shove. 2005. Infrastructures of consumption: environmental innovation in the utility industries. Earthscan, London and Sterling, VA.

Walton, A., J. Gardner, A. Sharma, M. Moglia, and G. Tjandraamadja. 2012. Exploring policy options for maintaining rainwater tank systems. Technical Report No. 59. Urban Water Security Research Alliance, City East, Queensland, Australia. 
${ }^{[1]}$ Interviews with government representatives were beyond the scope of this project, although they would usefully inform future work in this field.

${ }^{[2]}$ In South East Queensland, local councils introduced a rebate scheme from 2006-2009, i.e., the Home and Garden Water Wise Rebate Scheme. Households were given a rebate of AUD $\$ 1000$ for installing tanks at least $3000 \mathrm{~L}$ in capacity. From February 2008, this was extended to include a AUD\$1500 rebate for tanks $3000 \mathrm{~L}$ or bigger that were plumbed into at least one internal connection within the home. 